\title{
Habitat Relationships of Basin Wildrye in the High Mountain Valleys of Central Utah
}

\author{
G.R. WALKER AND J.D. BROTHERSON
}

\begin{abstract}
Habitat relationships between stands of basin wildrye (Elymus cinereus) and adjacent sagebrush-grass steppe were studied in the Strawberry Valley of central Utah. Fifteen sites of basin wildrye and 15 adjacent sites of sagebrush-grass steppe were selected and sampled for various biotic and abiotic environmental variables. Stands of basin wildrye were dominated by this grass ( $90 \%$ composition). The adjacent sagebrush-grass steppe exhibited more diversity of species and life forms. Basin wildrye and badger diggings were correlated $95 \%$ of the time. Potassium concentrations $(P<.05)$ and soil depth $(P<.01)$ were significantly greater in the basin wildrye sites. Secondary successional patterns were observed on disturbed sites.
\end{abstract}

Today's rangelands are important because of their potential for multiple use. In addition to forage for domestic livestock, they provide water, wild life habitat, many forms of recreation, purification of air, and esthetic values. As the human population increases and public demands on vital land resources also increase, precise knowledge of the ecological requirements of the natural plant cover of these lands will become increa singly useful. Native grasses are particularly valuable because of their contribution to the vegetative cover, available forage and community stability of these ranges. Basin wildrye (Elymus cinereus Scribn. and Merr.) is one of the important grasses of the western North America. This paper reports on basin wildrye and some of its ecological relationships in part of the Great Basin.

Named by John C. Fremont in 1844, the Great Basin is a physiographic area in western North America. Having somewhat indefinite boundaries it comprises most of Nevada and Utah with fringes in California, Oregon, Idaho, and Wyoming (Lesperance et al. 1978). Basin wildrye is common throughout the basin. It derives its scientific name from the Greek elumos, which was an ancient name for a kind of grain. The wildrye genus belongs to the barley tribe of grasses (Triticeae) which among others includes the wheat grasses and the grains wheat, barley, and rye. Basin wildrye occurs in all western states except New Mexico (U.S. Forest Service 1937). Hillman (1896) working in several areas of Nevada reported stems of basin wildrye attain heights of 10 feet but with most plants nearer 6 feet. Griffiths (1901) working in the Quinn River Valley, Nevada, reported thousands of acres of basin wildrye growing on the bottomlands and fringing outward into the sagebrush zone. Freighters of the last century reported that they never carricd hay for their oxen but turned them loose at evening in patches of the grass, which were so extensive, tall and dense that the beasts were sometimes lost for several days. Later the grass cover became so scanty on some of those same areas due to serious overgrazing that cattle were easily visible across the entire area (U.S. Forest Service 1937). Recent inventories indicate approximately 800,000 acres of potential basin wildrye habitat in the Humbolt River Basin. In addition, much of current cropland located along the Humbolt was

Authors are instructor of biology, Springville High School, Springville, Utah 84663 , and associate professor of botany and range science, Brigham Young University, 492 WIDB, Provo, Utah 84602

Manuscript received June 22,1981 . probably formerly dominated by basin wildrye. Therefore, the total habitat under prestine conditions was roughly a million acres or $10 \%$ of the entire basin (Lesperance et al. 1978).

Basin wildrye (according to the Plant Information Network, Ft. Collins, Colorado) occurs in a wide variety of communities such as fir and pine, mountain mahogany and oak, sagebrush and grass, saltbush and greasewood, wheatgrass and bluestem, as well as disturbed areas. It grows best on gentle to moderate slopes with an optimal 20-inch base of loam or sandy loam soil. Basin wildrye cover as value for habitat has been determined to be fair for elk and deer and good for antelope, birds and small mammals. Food value ranges from fair for elk, birds, and small mammals to poor for deer and antelope. Palatability of basin wild rye for domestic livestock varies from fair to good. Energy value is good and protein content is fair. In reclamation related studies the grass has been considered to have good potential for erosion control and long-term revegetation. Anthesis occurs from June to August (PIN 1980).

Data taken from specimens of basin wildrye deposited in the herbarium of Brigham Young University (Table 1) support the statistics obtained from the Plant Information Network (PIN) in Colorado. As shown the grass grows across a wide elevational gradient and was found in many community types in Utah. However, the data indicate the plant was found most often between

Table 1. Distribution and habitat within Utah of basin wildrye. Data were based on collections found at the herbarium of Brigham Young University. Forty-nine total sheets were examined. Data were collected from the labels of the sheets examined.

\begin{tabular}{|c|c|c|c|c|c|c|}
\hline & \multicolumn{6}{|c|}{ Elevation $^{1}(\mathrm{~m})$} \\
\hline & 1200 & 1500 & 1800 & 2100 & 2400 & 2700 \\
\hline \multirow{2}{*}{$\begin{array}{l}\text { Percent } \\
\text { of sheets } \\
\text { examined }\end{array}$} & 12 & 12 & 12 & 30 & 14 & 4 \\
\hline & \multicolumn{3}{|c|}{$\begin{array}{l}\text { Plant Community or } \\
\text { site condition }\end{array}$} & & \multicolumn{2}{|c|}{$\begin{array}{l}\text { Percent of sheets } \\
\text { examined }\end{array}$} \\
\hline & $\begin{array}{l}\text { Meadow } \\
\text { greasewo } \\
\text { sagebrus } \\
\text { pinyon-j } \\
\text { oak } \\
\text { mountai } \\
\text { lodgepol } \\
\text { aspen } \\
\text { douglas } \\
\text { spruce-fi } \\
\text { streamsic } \\
\text { washes a } \\
\text { roadside } \\
\text { other }\end{array}$ & $\begin{array}{l}\text { shadsc } \\
\text { ass } \\
\text { er } \\
\text { ush } \\
\text { ne } \\
\text { age } \\
\text { ditchb } \\
\text { d dist }\end{array}$ & d sites & & & \\
\hline
\end{tabular}

'Each designation of elevation includes a range of $300 \mathrm{~m}$. For example $1200=1499$ meters in elevation. Elevation was not recorded on $16 \%$ of the 49 sheets examined. ${ }^{2}$ Soil data were found to be indecisive or absent from collection labels, and therefore no attempt was made to cvaluatc soil data. 
2100 and $2400 \mathrm{~m}$ elevation and in the sagebrush-grass, streamside, and pinyon-juniper communities as well as along roadsides and in other disturbed areas. The grass is widely distributed in Utah.

In spite of the attractiveness of this plant to the range manager, basin wildrye has not been well studied. Lesperance et al. (1978) suggested that this may be due to the fact that once abundant stands have been grazed to depletion. He also indicated that low seed germination and poor seedling vigor of the plant when being worked with in the laboratory tended to frustrate plant breeders. A number of publications exist which report on the forage quality and grazing sensitivity of basin wildrye: (Hillman 1896, Griffiths 1901, Perry and Chapman 1974, Murray et al. 1978, and Lawrence 1978). Other research dealing with basin wildrye includes cytogenetics and hybridization (Dewey 1972 and 1972a), classification via epicuticular waxes (Tulloch and Hoffman 1977), germination problems (Frelich et al. 1973), vole habitat (Batzli 1974), resistance to rust (Chapman et al. 1975), response to copper contaminated substrates (Pengelly 1974), and environmental effects on turgor pressure (Johnson 1978). Little has been reported on the ecological relationships of basin wildrye.

The purpose of this study was to identify the ecological simila rities and differences between sites of basin wildrye and adjacent sagebrush-grass steppe in the Strawberry Valley, Utah. A precise knowledge of such relationships and differences should be of value to the range manager working within this vegetative zone and in identifying the potential of this plant in revegetation efforts.

\section{Study Area}

Strawberry Valley (Fig. 1) is located in northwestern Utah, Wasatch County, approximately $30 \mathrm{~km}$ southeast of Herber City, (Lat. $40^{\circ} 11^{\prime} 15^{\prime \prime} \mathrm{N}$, Long. $111^{\circ} 11^{\prime} 30^{\prime \prime} \mathrm{W}$ ). Topographical features include Strawberry Reservoir, tributary creeks, and low rounded hills approximately $20-100 \mathrm{~m}$ high (60-300 ft.) which are weathered from fluvial and lacustrine sediments of the Ecocene Uinta formation (England 1979).

The study area supports sedge-grass meadows in the valley bottoms, sagebrush-grass steppe in the intermediate elevations and

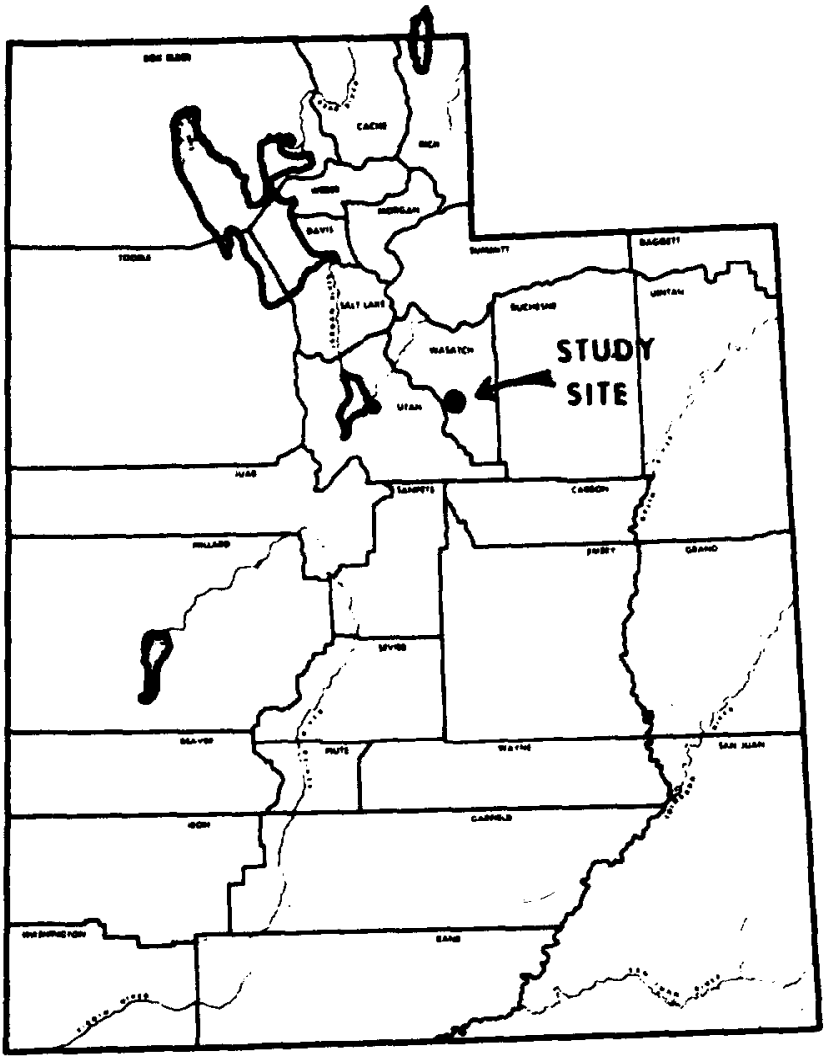

Fig. 1. Map of study site location in Utah. aspen-conifer forests at the highest elevations.

The climate of the area is characterized by cool summers and freezing winters accompanied by heavy snow cover. Annual precipitation averages $610 \mathrm{~mm}$ ( 24 inches) of which $60 \%$ falls as winter snow (England 1979). According to Thornthwaite (1933), the climate would be classified as Cc's (subhumid microthermal, precipitation deficient in the summer). Elevation at the study locations ranges from $2300 \mathrm{~m}$ (7600 ft.) to $2436 \mathrm{~m}$ (8040 ft.).

Soils were formed from weathered sandstone and siltstone. Soils located at hilltops were predominately lithic cryoborolls and lithic cryorthents. Those of mid slopes were a mixture of lithic and typic cryoborolls (USDA 1975, England 1979). Soils of the mid and bottom slopes were often extensively reworked by badgers and ground squirrels.

The area serves as a summer range for deer, elk, sheep, and cattle. In places, heavy grazing by domestic livestock is apparent, but the range is generally in good condition.

\section{Methods}

Vegetational data were gathered when most plant species had reached their maximum growth. Fifteen sites dominated by basin wildrye and 15 adjacent sites dominated by sagebrush-grass steppe were selected for study. The sites exhibited minimum evidence of direct human disturbance. Twenty additional sites were observed where badger and rodent activity were noted.

Study plots $(10 \mathrm{~m} \times 10 \mathrm{~m})$, established at each site were confined to the same slope, elevation and exposure. The plots were delineated by a $10 \mathrm{~m}$ cord attached to $1 \mathrm{~m}$ stakes. Flagging at $2 \mathrm{~m}$ intervals along the cord aided in uniform placement of 20 quadrats $(.5 \mathrm{~m} \times .5 \mathrm{~m})$, across the surface of each plot in 4 rows of 5 quadrats each.

The following characteristics were recorded for each plot: topographical position (ridgetop, midslope, or drainage accumulation area), aspect, elevation (topographical map), grazing impact, erosion, general animal activity, and number of badger and rodent burrows.

Average soil depth was determined at each plot with the use of a $1 \mathrm{~m}$ penetrometer (Greenwood and Brotherson 1978). Five measurements were taken, 1 at each corner and 1 in the middle of the plot. Soil samples were collected to a depth of $20 \mathrm{~cm}$ from 3 areas within the plot ( 2 adjacent corners and the middle).

Living plant cover, litter, exposed rock, bare soil, and individual species cover were estimated using the cover class categories suggested by Daubenmire (1959). Plant cover was subdivided into trees, shrubs, subshrubs, perennial forbs, perennial grasses, sedges, annual forbs, and biennial forbs for composition purposes. Total cover and frequency percentages were calculated for individual species, litter, bare soil and exposed rock. Percent composition and calculated for the 8 categories of plant cover. In addition, plants not appearing in any of the $0.25 \mathrm{~m}^{2}$ quad rats but still found within the -study plot were recorded and used in compiling an overall species, litter, bare soil and exposed rock. Percent composition was

Soil samples were analyzed for texture (percent sand, silt, clay, fines (silt plus clay) and gravel; Bouyoucos 1951), pH, soluble salts, organic matter and mineral content. Potassium, magnesium, calcium, and sodium ions were extracted with neutral normal ammonium acetate (Jackson 1958, Hesse 1971, Jones 1973). Individual ion concentrations were determined using a Perkin-Elmer Model 403 atomic absorption spectrophotometer (Isaac and Kerber 1971). Soil phosphorus was extracted by sodium bicarbonate (Olsen et al. 1954). Nitrite analysis was made using a macrokjeldahl procedure (Jackson 1958). Total soluble salts were determined by a Beckman Electrical Conductivity Bridge. A paste of 1:1 soil to water mixture (Russell 1948) was used to determine pH and soluble salts.

Data analyses consisted of computing means and standard deviations for each paired category. Parametric tests of significance were done by using a group $t$-test (Steel and Torrie 1960). Stand diversity values were computed using the equation $B=1 / \Sigma_{p i} 2$ 
where " $\mathrm{B}$ " is equal to the niche width and/or diversity and "pi" is a measure of the relative abundance of a species in a given habitat (Levins 1966, MacArthur 1972).

\section{Results and Discussion}

Dense stands of basin wildrye associated with elevated microtopography and varying degrees of disturbance and ranging in size from $3 \mathrm{~m} \times 3 \mathrm{~m}$ to $15 \mathrm{~m} \times 30 \mathrm{~m}$, are distributed throughout the sagebrush-grass steppe of the mountain valleys of central Utah. Because of their height (1-2 m) and strong homogenity, stands of basin wildrye show a distinct, green mosaic pattern on the midslopes and bases of the valley foothills (Figs. 2-5).

Sixty-one species of plants were identified from the study area. Table 2 lists the most prevalent species of each community and their average percent cover values. Prevalent species were chosen for each community on the basis of the mean number of plant species per stand. Basin wildrye communities averaged 9 species per stand, while the sagebrush-grass steppe community had 13 prevalent species.

Basin wildrye stands supported a total living aerial cover of $91 \%$ while the adjacent sagebrush-grass stands supported $77 \%$ total cover (Table 3 ). Basin wild rye also averaged $76 \%$ cover on the sites studied compared to the next most prevalent species, Richardson geranium (Geranium richardsonii), with an average $3 \%$ cover (Table 2). The population of basin wildrye individuals was highly dense often to the exclusion of other species. Other species present were insignificant in comparison and grew mainly on the outer edge of the community or along edges of game trails and openings within the community.

The sagebrush-grass steppe community exhibited an increa se in diversity and life forms when compared to the basin wildrye community. Shrubs provided the main canopy with grasses, forbs, and subshrubs the understory. Mountain sagebrush (Artemisia tridentata var. vaseyana) was the most important species ( $20 \%$ average cover). As evidence of abundance of species, and diversity, the next eleven prevalent species had but $8 \%$ average cover spread between them (Table 2). Basin wildrye was rarely found in this community.

Table 3 lists the means, standard deviations and significance levels of the various factors analyzed for the stands of ba sin wildrye

Table 2. Prevalent species lists for the basin wildrye and adjacent sagebrush-grass steppe communities in the Strawberry Valley of central Utah. Numbers represent species importance in the community in average
percent cover.

\begin{tabular}{lc}
\hline \hline Species & Average \% cover \\
\hline Basin wildrye community & \\
Elymus cinereus & 76.4 \\
Geranium richardsonii & 3.0 \\
Chrysothamnus viscidiflorus & 2.7 \\
Artemisia tridentata & 2.3 \\
Stipa lettermanni & 2.3 \\
Chrysothamnus nauseosus & 1.1 \\
Stipa comata & 0.9 \\
Agropyron dasystachium var. riparium & 0.9 \\
Agropyron spicatum & 0.6 \\
Sagebrush-grass steppe community & \\
Artemisia tridenta var. vaseyana & \\
Chrysothamnus viscidiflorus var. lanceolatus & 19.6 \\
Stipa comata & 11.7 \\
Stipa lettermanni & 9.3 \\
Geranium richardsonii & 8.5 \\
Lupinus argenteus & 4.3 \\
Agropyron dasystachium var. riparium & 4.6 \\
Eriogonum heracleoides & 3.3 \\
Aster chilensis ssp. adscendens & 2.8 \\
Festuca idahoensis & 2.6 \\
Penstemon subglaber & 1.7 \\
Agropyron spicatum & 1.6 \\
Stipa columbiana & 1.3 \\
\hline & 1.0 \\
\hline
\end{tabular}

and adjacent sagebrush-grass steppe. The level of significance given for each factor indicates the value of that factor as a discriminator between the two community types.

Elevation as a discriminator between the communities was of no significance due to the methodology employed in sampling (i.e. sites were studied in adjacent pairs). Elevation averaged $2,373 \mathrm{~m}$ $(7,831 \mathrm{ft}$.) and varied between $2,303 \mathrm{~m}$ and 2,424 $\mathrm{m}$ at different locations. Percent litter and exposed rock averages were greater in the sagebrush-grass community but the differences were nonsignificant (Table 3). The average site of basin wildrye was located midslope facing $206^{\circ}$ southwest. Individual aspect readings varied between $125^{\circ}$ and $280^{\circ}$ but differences were not statistically significant (Table 3).

Percent exposed soil was significantly greater in the sagebrushgrass steppe (17\%) when compared to basin wildrye (8\%) (Table 3).

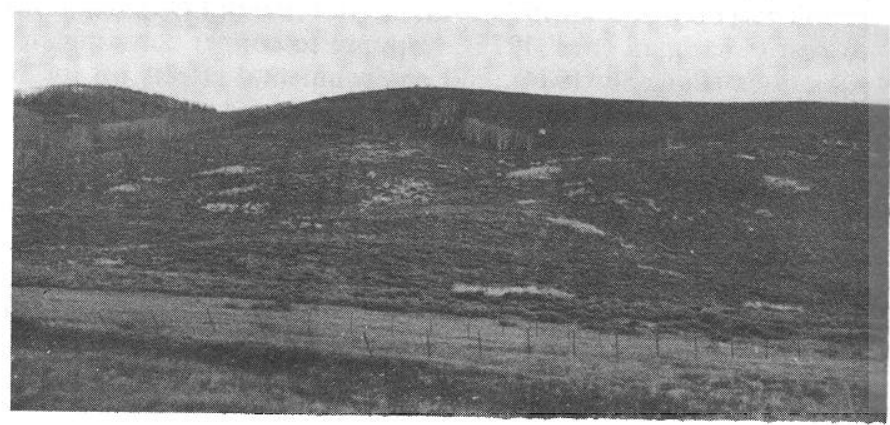

Fig. 2. Stands of basin wildrye scattered across the foothills in the Strawberry Valley, Utah.

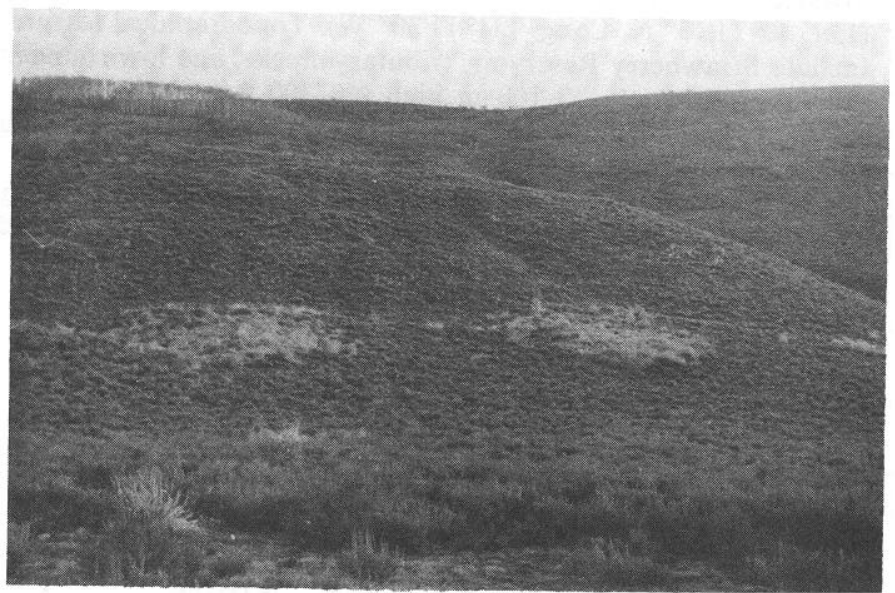

Fig. 3. Several stands of basin wildrye at the midslope position on the foothills in the Strawberry Valley, Utah.

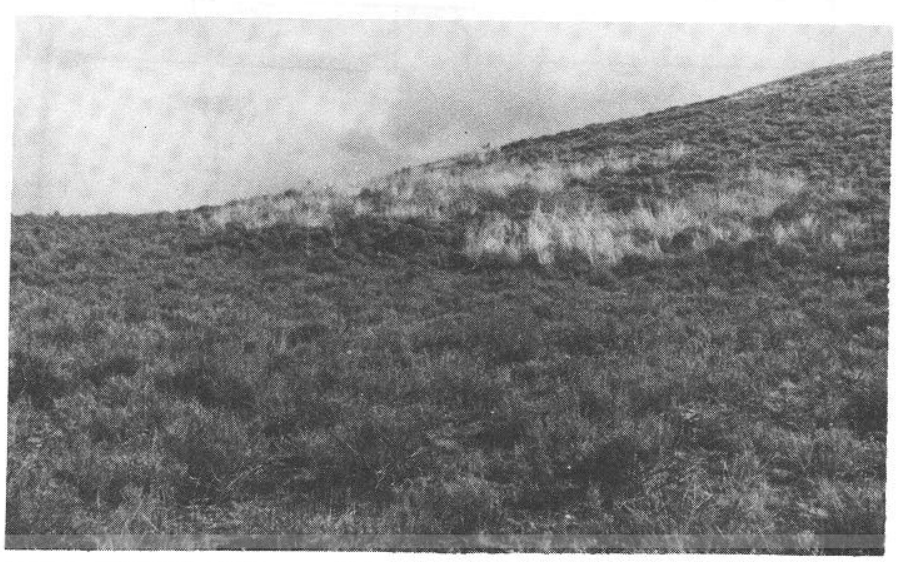

Fig. 4. Closeup of two small stands of basin wildrye of midslope within the sagebrush-grass steppe community. 
Table 3. Measured environmental factors along with their means, standard deviations, and indications of significant differences in the means relative to basin wildrye and adjacent sagebrush-grass steppe communities in the Strawberry Valley of central Utah. Statistical differences computed by group t-test.

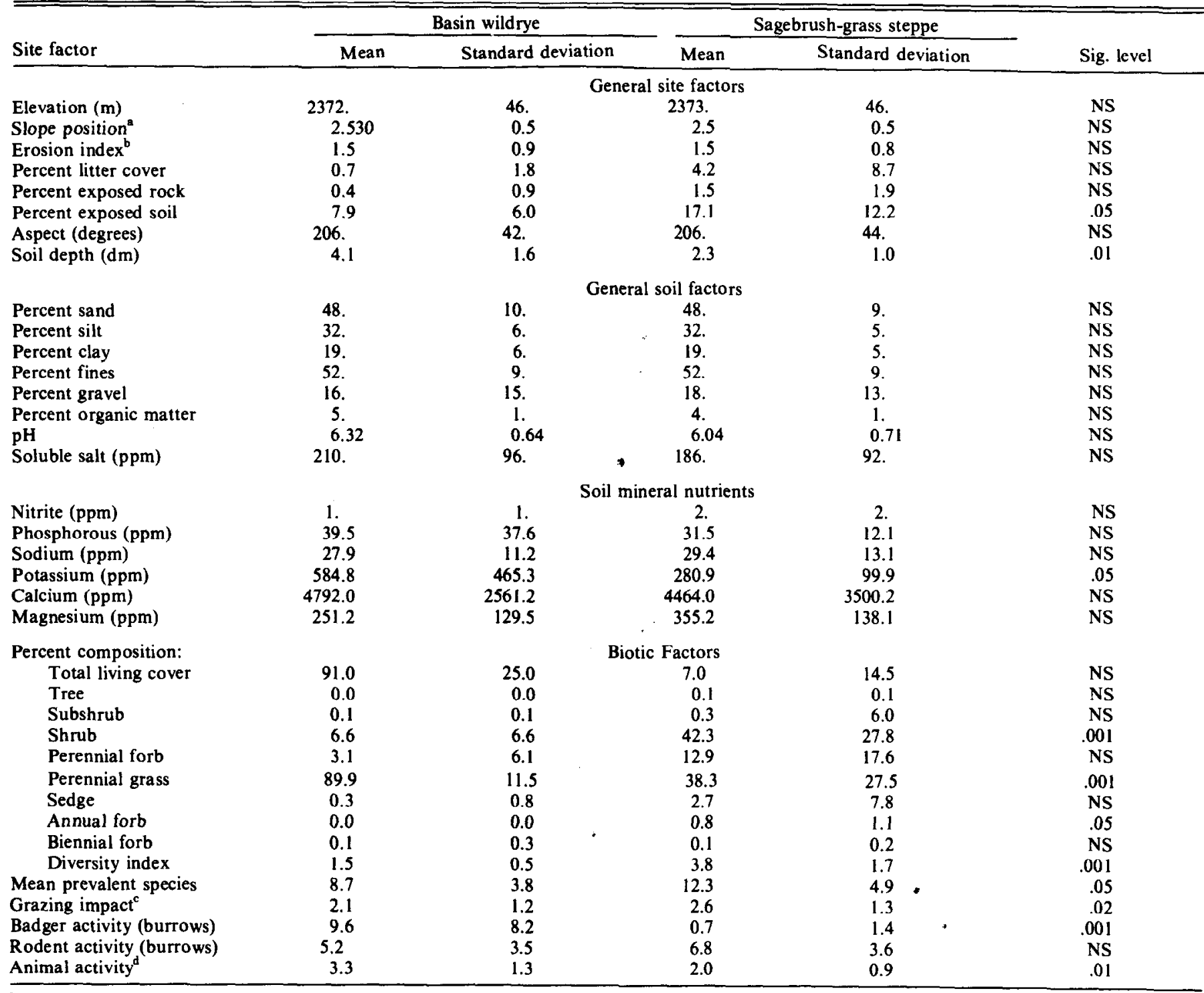

Slope position defined as $1=$ top of slope, $2=$ midslope, $3=$ bottom of slope.

brosion index runs from 1 to 4 with 1 indicating no erosion and 4 indicating heavy erosion.

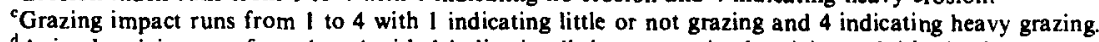

${ }^{\mathrm{d}}$ Animal activity runs from 1 to 4 with 1 indicating little or no animal activity and 4 indicating heavy animal activity.

This indicated that the vegetation in the basin wildrye stands was denser than in the sagebrush-grass steppe. Soil depth (Table 3) averaged almost $2 \mathrm{dm}$ more in the basin wildrye stands (partially a result of badger activity), and appeared to be highly significant in encouraging the growth of the grass with its extensive root system (PIN 1980).

Soil texture varied little between the community types and can be classed as a sandy loam. Average percent gravel differed (Table 3) slightly with $16 \%$ in the basin wildrye community as opposed to $18 \%$ in the sage-grass community. The $\mathrm{pH}$ of the soils was lower in the sagebrush community, 6.04 to 6.32 but the difference was not significant (Table 3).

As shown in Table 3, potassium concentrations were significantly higher in the basin wildrye communities ( $584 \mathrm{ppm}$ ) than in the sagebrush-grass steppe community $(281 \mathrm{ppm})$. Soil samples were taken to a depth of $20 \mathrm{~cm}$ in all 30 stands. Leeching of cations such as potassium out of the root zones and into lower soil depths occurs across much of the original sagebrush-grass steppe. The higher concentrations of potassium in the surface horizons of basin wildrye stands may be the result of soil stirring through badger digging or the mining of deeper horizons by basin wildrye roots and then redisposition through through biomass decay.

Analysis of growth forms showed important differences between the basin wildrye and sagebrush-grass steppe communities. Plant species were placed into 8 growth form categories (Table 3). Mean composition values were used for group comparisons. Based on composition there was a highly significant difference in the presence of shrubs, perennial grasses and annual forbs between the 2 communities. Shrubs comprised $36 \%$ more cover in the sagebrushgrass community. Perennial grass comprised $51 \%$ more cover in the basin wildrye community where annual forbs were completely absent. The significance of perennial grass in the basin wildrye community is due entirely to the extreme dominance of basin wildrye. Other perennial grasses were present in the community understory, but did not exert a dominance due to their smaller size and reduced distribution. Shrubs were infrequent on the sites and 


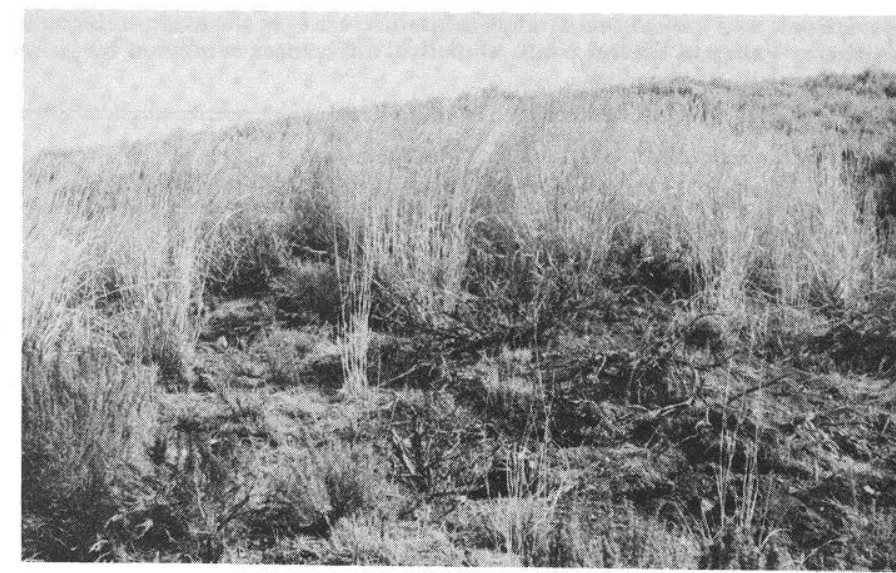

Fig. 5. Closeup of basin wildrye stand and associated badger digging activity.

occurred only sparsely in the dense stands. Immediately on the perimeter of the basin wildrye communities, the shrubs and other perennial grasses return to dominance.

Grazing impact was significantly higher on the sagebrush-grass steppe (Table 3 ) than on the basin wild rye site s probably because of the low palatability and coarser habit of basin wildrye. The only grazing that did occur on basin wild rye was on young shoots. The understory of the sagebrush-grass community was rich in Stipa, Agropyron, Festuca and Penstemon, which were all grazed. In areas of heavy grazing where this understory was almost totally depleted, stands of basin wildrye were virtually untouched.

The measure of average diversity was significantly higher $(p<.001)$ in the sagebrush-grass steppe which demonstrated an increased number of species as well as an increased relative abundance of those species. The lower average number of species per stand in the basin wildrye sites also reinforced the dominance and homogeneous nature of the community (Table 3 ).

Close inspection of individual basin wildrye stands clearly revealed an association with badger (Taxidea taxus) activity. Mounds of reworked soil, a direct result of 9 or 10 badger burrows, provided an avenue for the establishment of basin wildrye within the sagebrush-grass steppe community. Observations showed badger diggings and dense stands of basin wildrye correlated approximately $95 \%$ of the time. Less often, basin wildrye stands were found in other disturbed sites along creek banks and on erosion outwash areas. The uniform nature of the soil texture throughout the study area appeared to be unrestricting to badger activity. This is reflected in the apparent random distribution of the diggings.

General a nimal activity (natives rodents, etc.) on a scale of 1 to 4 ( 1 indicating low activity) was significantly higher in the basin wildrye community (Table 3 ) than in the sagebrush-grass steppe community. Most of this significance was due to badger activity. Small rodent burrows were more numerous in the sagebrush-grass sites but were not statistically different. Badger burrows, while rare in the sagebrush-grass area, averaged 9.6 burrows in sampled basin wildrye sites, and thus were significantly higher $(p<.001)$ in occurrence.

In studying the significance of badger activity further, a successional pattern was observed. Several active burrow sites, free of basin wildrye growth, were located in the sage-grass area at some distance from existing stands of basin wildrye. Transitional sites with young shoots and sparse growth of basin wildrye growing on the badger tailings were also located. The original climax sagebrush-grass steppe vegetation seemed to be disturbed by badgers resulting in areas open to invasion by basin wildrye. Old stands of basin wildrye with abandoned, weather burrows presented evidence of a return to sagebrush-grass steppe climax. The less dense basin wildrye population, noticeably higher in percent litter, give way to sagebrush rabbitbrush (Chrysothamnus nauseo- sus) reinvasion. Letterman needlegrass (Stipa lettermanni) and several species of wheat grass were also more prevalent with these stands. Livestock grazing of young basin wildrye shoots may have contributed to the decline of these communities due to the intolerance of this grass to grazing pressure.

In general, several basic trends can be observed. Basin wild rye is positively associated with disturbance in the Strawberry Valley. Badger activity in the sagebrush-grass steppe appears to be the main catalyst that provides a pathway for establishment of basin wildrye. Leached potassium concentrations are higher at the soil surface in basin wildrye stands. The increased soil depth in the mound areas provide a suitable habitat for the growth of basin wildrye. Soil surface crust breakdown may also be a factor in basin wildrye establishment due to its germination sensitivity (Johnson 1978). Once established, basin wildrye strongly dominates a site. Secondary successional patterns can be observed on disturbed sites indicating a potential for the use of basin wildrye in revegetation efforts.

\section{Literature Cited}

Batzli, G.O. 1974. Influence of habitat structure on a population of voles. Bull. South. California Acad. Sci. 73:83-85.

Bouyoucos, G.J. 1951. A recalibration of the hydrometer for making mechanical analysis of soils. J. Agron. 43:434-438.

Chapman, S.R., E.L. Sharp, and B.K. Sally. 1975. Possible simple inheritance of resistance to stripe rust in basin wildrye. Phytopathology 65:409411.

Cronquist, A., A.H. Holmgren, N.H. Holmgren, J.L. Reveal, and P.K. Holmgren. 1977. Intermountain flora. Vol. 6 Vascular plants of the Intermountain West-USA. 504 p.

Daubenmire, R. 1959. A canopy-coverage method of vegetational analysis. Northwest Sc. 33:43-46.

Dewey, D.R. 1972. Cytogenetics of Elymus angustus and its hybrids with Elymus giganteus, Elymus cinereus and Agropyron repens. Bot. Gaz. 133:57-64.

Dewey, D.R. 1972a. Genome analysis of hybrids between diploid Elymus junceus and 5 tetraploid elymus species. Bot. Gaz. 133:415-420.

England, J.L. 1979. Measured and inferred moisture gradient relationships: A study of montane steppe in central Utah. M.S. Thesis, Dept. Botany and Range Science, Brigham Young University, Provo, Utah 36 p.

Frelich, J.R., E.H. Jensen, R.O. Gifford. 1973. Effect and crust rigidity and osmotic potential on emergence of 6 grass species. Agron. J. 65:26-29.

Greenwood, L.R., and J.D. Brotherson. 1978. Ecological relationships between pinyon juniper and true mountain mahogany stands in the Uintah Basin, Utah. J. Range Manage. 31:164-167.

Griffiths, D. 1901. Forage conditions on the northern border of the Great Basin. Bull. 15. Bureau of Plant Industry, USDA. 60 p.

Hesse, P.R. 1971. Textbook of soil chemical analysis. William Clowes and Sons Ltd., London. 520 p.

Hillman, F.H. 1896. Field notes on some Nevada grasses Agr. Exp. Sta., Nevada State Univ. Bull. 33. 13 p.

Hitchcock, A.S., and A. Chase. 1971. Manual of the grasses of the U.S. Vol. I and II. Dover Publications, Inc. New York. 1051 p.

Isaac, R.A., and J.D. Kerber. 1971. Atomic absorption and flame photmetry: techniques and uses in soil, plant, and water analysis. In: L.M. Walsh (ed.). Instrumental methods for analysis of soils and plant tissue. Soil Sci. Soc. Amer. Wisc. p. 17-38.

Jackson, M.L. 1958. Soil chemical analysis. Prentice-Hall Inc., Englewood Cliffs, N.J. 498 p.

Johnson, D.A. 1978. Environmental effects on turgor pressure response in range grasses. Crop. Sci. 18(6):945-948.

Jones, J.B. 1973. Soil testing in the United States, Comm. Soil Sci. Plant Anal. 4:307-322.

Lawrence, T. 1978. An evaluation of 30 grass populations as forage crops for southwestern Saskatchewan, Canada. Can. J. Plant Sci. 58:107-116.

Lesperance, A.L., J.A. Young, R.E. Eckert, Jr., and R.A. Evans. 1978. Great Basin Wildrye, Rangeman's J. 5:125-127.

Levins, R. 1966. The strategy of model building in ecology. Am. Sci. 54:421-431.

MacArthur, R.H. 1972. Geographical ecology-patterns in the distribution of species. Harper and Row, New York. 251 p.

Murray, R.B., H.F. Mayland, P.J. van Soest. 1978. Growth and nutritional value to cattle of grasses on cheat grass range in southern Idaho, USA U.S. For. Serv. Res. PAP Int. 199:1-57. 
Olsen, S.R., C.V. Cole, F.S. Watanabe, and L.A. Dean. 1954. Estimation of a vailable phosphorus in soils by extraction with sodium bicarbonate. U.S. Dept. Agr. Cir. No. 939. 17 p.

Pengelly, A. 1974. Response of Elymus cinereus, basin wildrye to copper contamination of the substrate. Proc. Mont. Acad. Sci. 34:49.

Perry, L.J., and S.R. Chapman. 1975. Effects of clipping on dry matter yields of basin wildrye. J. Range Manage. 28:271-273.

Perry, L.J., Jr., and S.R. Chapman. 1974. Effects of clipping on carbohydrate reserves in basin wildrye. Agron. J. 66:67-69.

Plant Information Network. 1980. Fish and Wildlife Ser. U.S. Dept. Int., Western Energy and Land Use Team, Ft. Collins, Colo.

Russell, E.W. 1973. Soil Conditions and Plant Growth. 10th ed. Jarrold and Sons Ltd., Norwich, Great Britian. 849 p.
Steel, R.G.D., and J.H. Torrie. 1960. Principles and Procedures of Statistics. McGraw-Hill Book Co. Inc. N.Y. 384 p.

Thornthwaite, C.W. 1933. The climates of the earth, a new and original method of climate classification. Geog. Rev. 28:400-433.

Tulloch, A.P., and L.L. Hoffman. 1977. Composition of epicuticular waxes of some grasses. Can. J. Bot. 55:853-857.

U.S. Dep. Agr., Soil Conservation Service 1975. Soil taxonomy. Agr. handbook. p. 436-754

U.S. Forest Service. 1937. Range plant handbook. U.S. Dep. Agr. U.S. Govt. Printing Office, Washington, D.C. p. 50-52.

Welch, S., and G. Moore. 1973. Utah Plants: tracheophyta. 3rd ed. Brigham Young University Press. Provo, Utah. 474 p.

\section{RANGELAND HYDROLOGY}

by Farrel A. Branson, Gerald F. Gifford, Kenneth G. Renard, and Richard F. Hadley

Unique in its emphasis on the hydrology of rangelands, primarily arid and semiarid lands, RANGELAND HYDROLOGY provides a text for one aspect of range management where none has existed before. This expanded Second Edition presents in-depth information for those who must manage rangeland or respond to questions about the impacts of land use practices on hydrology.

Included in the new Second Edition are a chapter on modeling with approaches to predicting the effects of land use, and a chapter on the rapidly developing field of snow pack management.

The 352-pages include 197 illustrations, providing rapid access to an assembly of data found nowhere else and useful in the preparation of environmental impact statements. Extensive bibliographic material with each chapter and a subject matter index add to the useableness of the book.

Range scientists and managers, soil conservationists, hydrologists, agricultural engineers, land reclamation specialists, wildlife managers, graduate and undergraduate students and their professors, as well as all interested in the hydrology of arid lands will find RANGELAND HYDROLOGY a valuable addition to their libraries. (352 pages paper laminated cover $\$ 15.00$ US)

Please send me copy(ies) of The Society For Range Management's Second Edition of RANGELAND HYDROLOGY by Branson et al. at $\$ 15.00$ each. Bill me (plus postage and handling)

Check enclosed (Kendall/Hunt pays shipping and handling)

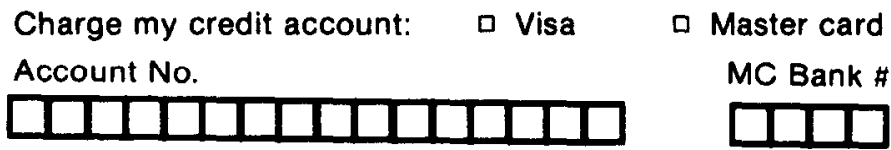

Exp. Date Signature (required for all charges)

I would like to have one examination copy, free for thirty days. If I decide to keep it, I will be billed at the single copy rate.

Name

Address City, State/ZIP 